\title{
Gastric T lymphocyte responses to Helicobacter pylori in patients with $H$ pylori colonisation
}

\author{
X J Fan, A Chua, C N Shahi, J McDevitt, P W N Keeling, D Kelleher
}

\begin{abstract}
Helicobacter pylori has been identified as a dominant factor in the pathogenesis of duodenal ulcer. The aim of this study was to examine peripheral blood and gastric lymphocyte proliferation and cytokine production in patients with $H$ pylori colonisation. Sixty five dyspeptic patients attending for endoscopy were studied; 35 of these were $H$ pylori positive and 30 $H$ pylori negative as assessed by culture, histology, and rapid urease test. $H$ pylori antigen was capable of stimulating peripheral blood lymphocyte proliferative responses even in $H$ pylori negative patients. Peripheral blood lymphocyte proliferative responses to $H$ pylori (but not to purified protein derivative or phythaemagglutinin) were significantly lower in $H$ pylori positive than $H$ pylori negative patients. Similarly, antigen specific proliferative responses and interferon $\gamma$ production by gastric lamina propria lymphocytes were also depressed in $H$ pylori positive patients compared with $H$ pylori negative patients. $C D 8$ and CD22 positive lamina propria lymphocytes were increased in $H$ pylori positive patients. These data show that antigen specific responses to $H$ pylori are significantly lower in $H$ pylori positive patients and could indicate activation of antigen specific suppression

(Gut 1994; 35: 1379-1384)
\end{abstract}

Helicobacter pylori ( $H$ pylori, previously known as Campylobacter pylori) is a spiral organism ${ }^{12}$ that colonises the human gastric epithelium. ${ }^{3}$ It is strongly associated with chronic type B gastritis and peptic ulcer disease. ${ }^{4-7}$ Eradication of the bacterium is associated with healing of gastric and duodenal ulcer and longterm remission suggesting that this is a dominant factor in the pathogenesis of peptic ulcer. ${ }^{8-10} H$ pylori colonises the gastric antrum but can also be found in the corpus and duodenum in regions of gastric metaplasia. ${ }^{11}$ Colonisation of the stomach with $H$ pylori is accompanied in the acute stage by an increased number of neutrophils in the lamina propria. In the chronic stage, an increase in the number of lymphocytes, plasma cells, and eosinophils in the lamina propria is evident. ${ }^{12}$ The infection is also associated with both a local and systemic specific antibody immune response. ${ }^{13-15}$ The contribution, however, of $\mathrm{T}$ cell responses to host defences to $H$ pylori is little understood. It has previously been reported that peripheral blood lymphocyte responses to $H$ pylori are reduced in $H$ pylori positive patients. ${ }^{1617}$ It has been suggested that reduction in peripheral blood lymphocyte responses might simply reflect a selective accumulation of antigen specific $\mathrm{T}$ cells in mucosal sites. In this study, we have developed a system to examine antigen specific $T$ cell responses to $H$ pylori in the gastric lamina propria lymphocytes. Gastric lymphocytes were isolated by a modification of techniques developed for the isolation of small bowel lymphocytes from intestinal biopsy specimens. ${ }^{18}$ Antigen specific responses could be analysed if an exogenous source of antigen presenting cells and cytokine was provided in the form of irradiated autologous peripheral blood mononuclear cells and low dose interleukin 2 , respectively.

\section{Methods}

SUBJECTS

Sixty five dyspeptic patients attending for upper gastrointestinal endoscopy for dyspepsia were studied (35 females, 30 males, age range:17-78 years; mean age: $49 \cdot 6$ ), all of whom had antral biopsies performed. None of the patients studied had received non-steroidal anti-inflammatory drugs, bismuth compounds or antibiotics recently. Patients with evidence of malignant disease or immunosuppression were excluded. Multiple biopsy specimens were obtained during upper gastrointestinal endoscopy from adjacent sites of the gastric antrum for $H$ pylori culture, histological examination, and rapid urease test (CLO test). $H$ pylori was identified histologically by a Giemsa stain. $H$ pylori were grown on $7 \%$ lysed horse blood agar under microaerophilic conditions at $37^{\circ} \mathrm{C}$ for three days. Patients were designated as $H$ pylori positive on the basis of CLO testing. Preliminary analysis on 37 patients showed that CLO testing had a 94\% sensitivity for $H$ pylori positivity with respect to culture and a $100 \%$ specificity. Table I summarises the patient characteristics.

\section{ANTIGEN AND MITOGEN PREPARATION}

$H$ pylori antigen was prepared from a mixture of $H$ pylori cultures obtained from six patients. Bacteria cells were harvested in phosphate buffered saline and then washed $(\times 3)$ in phosphate buffered saline by centrifugation $(12000 \times g)$ for 15 minutes at $10^{\circ} \mathrm{C}$. The cells were resuspended in phosphate buffered saline $(1: 2 \mathrm{vol} / \mathrm{vol})$. This suspension was then sonicated on ice using $6 \times 15$ second 100 Watt pulses, with 30 second cooling intervals in between, using a DAWE Soniprobe $7532 \mathrm{~A} .{ }^{19}$ 
TABLE I Characteristics of the patients studied for peripheral blood mononuclear cells and lamina propria lymphocytes response. Patients were designated as $\mathrm{H}$ pylori positive on the basis of CLO testing. Preliminary analysis of 37 patients showed that CLO testing has a $94 \%$ sensitivity for $\mathrm{H}$ pylori positivity with respect to culture and a $100 \%$ specificity. Patient characteristics are summarised in the Table

\begin{tabular}{lll}
\hline & $\begin{array}{l}\text { HP+ve on the } \\
\text { CLO test } \\
(n=33)(\%)\end{array}$ & $\begin{array}{l}\text { HP-ve on the } \\
\text { CLO test } \\
(n=32)(\%)\end{array}$ \\
Characteristics & $30 / 33(91)$ including & \\
\hline Endoscopic gastritis & $\begin{array}{l}2 \text { cases of peptic ulcer } \\
\text { Histological gastritis }\end{array}$ & $\begin{array}{l}33 / 33(100) \\
4 / 32(16)\end{array}$ \\
HP seen on staining & $31 / 33(94)$ & $0 / 32(0)$ \\
\hline
\end{tabular}

The $H$ pylori protein concentration in the preparation was measured by the method of Bradford using bovine serum albumin as the standard. ${ }^{20}$ The sonicated preparation of $H$ pylori was irradiated at $400 \mathrm{~Gy}$ and stored at $-20^{\circ} \mathrm{C}$. Purified protein derivative (DK-2300 Copenhagen, Denmark) and phythaemagglutinin (Sigma Chemical, St Louis, MO, USA) were used at a concentration of $100 \mathrm{U} / \mathrm{ml}$ and $10 \mu \mathrm{g} / \mathrm{ml}$, respectively. Escherichia coli ( $E$ coli) antigen was prepared by inactivating the bacteria by irradiation and sonication as described above and used at a protein concentration of $2 \mathrm{mg} / \mathrm{ml}$. The optimum concentration of $H$ pylori for use in the lymphocyte proliferation studies was determined in preliminary experiments.

\section{PERIPHERAL BLOOD LYMPHOCYTE}

PROLIFERATION STUDIES

Peripheral blood samples were obtained by venesection for isolation of peripheral blood mononuclear cells. Peripheral blood mononuclear cells were separated by Ficoll-hypaque density gradient centrifugation at $250 \times g$ for 30 minutes at $4^{\circ} \mathrm{C}$ (Lymphoprep Nycomed Pharma AS, Oslo, Norway), then washed ( $\times 3)$ and resuspended in RPMI 1640 (Gibco, Life Technologies Ltd, Paisley, Scotland) medium containing $100 \mathrm{U} / \mathrm{ml}$ penicillin, $100 \mu \mathrm{g} / \mathrm{ml}$ streptomycin, $2 \mathrm{mM}$ L-glutamine, and $10 \%$ fetal calf serum. To assess antigen specific lymphocyte proliferation, $1 \times 10^{6} / \mathrm{ml}$ peripheral blood mononuclear cells were cultured in a total volume of $200 \mu \mathrm{l}$ for five days with varying amounts of $H$ pylori, purified protein derivative, phythaemagglutinin, $E$ coli or without stimulant (spontaneous cultures). ${ }^{3} \mathrm{H}$-thymidine

TABLE II Proliferative response of peripheral blood mononuclear cells to $\mathrm{H}$ pylori. Results are expressed as ${ }^{3} \mathrm{H}$-thymidine incorporation (cpm) in peripheral blood mononuclear cells cultured for five days

\begin{tabular}{llll}
\hline & \multicolumn{3}{l}{${ }^{3}$ H-thymidine incorporation $(c p m)$} \\
\cline { 2 - 4 } & $\begin{array}{l}\text { H pylori }(+) \\
(n=21)\end{array}$ & $\begin{array}{l}\text { H pylori }(-) \\
(n=16)\end{array}$ & $p$ Value \\
\hline Phythaemagglutinin $(10 \mu \mathrm{g} / \mathrm{ml})$ & $9510(1552)$ & $10417(2156)$ & $0 \cdot 72$ \\
Purified protein derivative $(100 \mathrm{U} / \mathrm{ml})$ & $4771(1613)$ & $8109(2466)$ & $0 \cdot 08$ \\
H pylori $(3 \mu \mathrm{g} / \mathrm{ml})$ & $1601(555)^{\star}$ & $3946(778)^{\star}$ & 0.018 \\
E coli $(2 \mu \mathrm{g} / \mathrm{ml})$ & $529(155)$ & $752(182)$ & $0 \cdot 39$ \\
Spontaneous RPMI & $745(190)$ & $954(221)$ & 0.35 \\
\hline
\end{tabular}

^Proliferative responses were significantly lower $(p<0.02)$ in the $H$ pylori positive group compared with $H$ pylori negative patients. There were no significant differences between the two groups after stimulation with phythaemagglutinin, purified protein derivative, $E$ coli, and RPMI control. Data shown as mean (SEM).
(1 $\mu \mathrm{Ci} / \mathrm{ml}$, specific activity $74 \mathrm{GBq} / \mathrm{mmol}$, NEN, Boston, MA) was added for the last 24 hours of culture. All samples were measured in triplicate. The cultured cells were harvested on Whatman paper using a cell harvester (Multimash 2000, Dynatech). Radioactivity incorporated into cells were determined by liquid scintillation counting using a Packard Tri-Carb scintillation counter. Lymphocyte proliferation assays were expressed as ${ }^{3} \mathrm{H}$-thymidine incorporation (cpm).

GASTRIC MUCOSAL LYMPHOCYTE CULTURE Lamina propria lymphocytes were separated by modification of techniques developed for the isolation of lymphocytes from duodenal mucosal biopsy specimens. ${ }^{21}$ Five gastric mucosa specimens were placed in Hanks's balanced salt solution without calcium and magnesium (CMF HBSS Gibco, $+5 \%$ fetal calf serum) containing $1 \mathrm{mM}$ dithiothreitol (Sigma) and $1 \mathrm{mM}$ ethylenediamine tetraacetic acid (Analar, BDH Chemicals Ltd, Poole, England) in a $20 \mathrm{ml} \mathrm{V}$ bottomed container. The specimens were then agitated for one hour at $37^{\circ} \mathrm{C}$ (Matburn blood cell suspension mixer), to remove the epithelial layer and washed with RPMI 1640. The specimens were treated with collagenase, type I (120 U/ml, Sigma) for three hours at $37^{\circ} \mathrm{C}$ with agitation. The cellular supernatant was then washed three times and the number and viability $(>85 \%)$ of the isolated lamina propria lymphocytes determined using acridine orange/ethidium bromide. Viability of lamina propria lymphocytes was consistently greater than $85 \%$. Lymphocytes were cultured $\left(4 \times 10^{5} / \mathrm{ml}\right)$ with $H$ pylori $(300 \mu \mathrm{g} / \mathrm{ml})$, phythaemagglutinin $(5 \mu \mathrm{g} / \mathrm{ml})$, and anti-CD3 (OKT3, 1:50) for three days (at $37^{\circ} \mathrm{C}$ in $5 \%$ carbon dioxide) with irradiated (250 Gy) autologous peripheral blood mononuclear cells $\left(2 \times 10^{6} / \mathrm{ml}\right)$ in a final volume of $200 \mu \mathrm{l}$ in RPMI 1640 medium containing interleukin 2 $(2 \mathrm{U} / \mathrm{ml})$ in $96-$ well $\mathrm{U}$ bottom microplates. ${ }^{3} \mathrm{H}$-thymidine was added for the last 24 hours of culture. All samples were measured in triplicate. The cultured cells were processed as described earlier.

\section{B LYMPHOCYTE ELIMINATION FROM LAMINA PROPRIA}

Lamina propria lymphocytes were incubated with Leu 14 (CD22): ( $5 \mu$ l for every $2 \times 10^{5}$ positive cells) for 45 minutes at $4^{\circ} \mathrm{C}$ with mixing and then washed. Magnetic beads coated with goat antimouse immunoglobulin G (IgG) (Dynabeads M-450) were added to the cell suspension: ( 10 beads: 1 positive cell) and the mixture was then incubated for 50 minutes at $4^{\circ} \mathrm{C}$ with mixing. RPMI 1640 (4 $\mathrm{ml}$ ) was then added and the $B$ cells were removed on a magnetic particle concentrator (DYNAL MPC 1). ${ }^{22}$ Non-adherent cells were collected and $\mathrm{CD} 22$ positive cells quantitated by flow cytometry before and after CD22 depletion. The cellular supernatant was then washed three times and the number and 


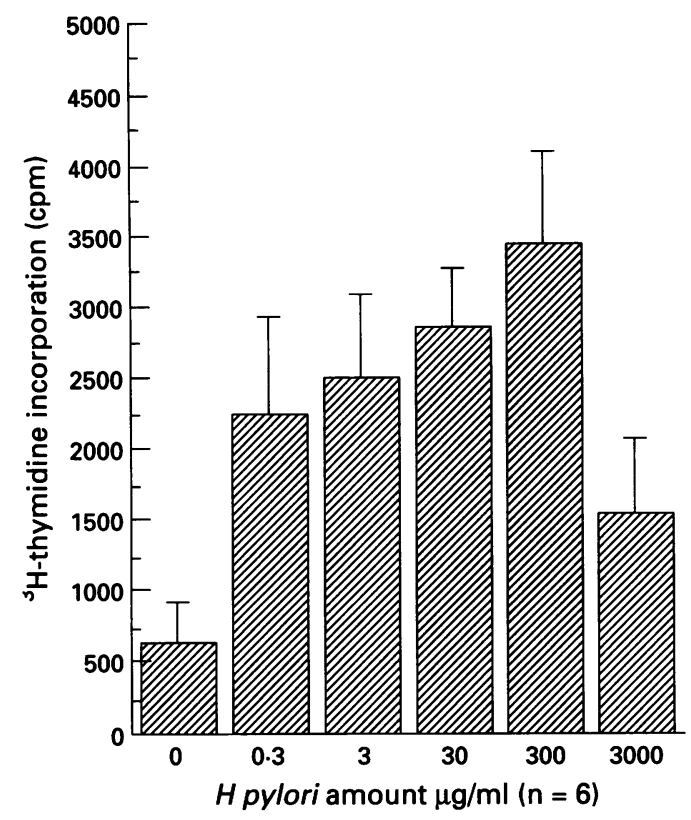

Figure 1: Dose response curve for the proliferation of lamina propria lymphocytes in response to $\mathrm{H}$ pylori. The effect of different amounts of $\mathrm{H}$ pylori on ${ }^{3} \mathrm{H}$-thymidine incorporation (cpm) into lamina propria lymphocytes $\left(4 \times 10^{5} / \mathrm{ml}\right)$ was estimated in the presence of irradiated (250 Gy) autologous peripheral blood mononuclear cells $\left(2 \times 10^{6} \mathrm{ml}\right)$ and interleukin $2(2 \mathrm{U} / \mathrm{ml})$ after a three day culture. Maximal proliferation was found at $300 \mu \mathrm{g} / \mathrm{ml}$ and this amount was used in subsequent experiments.

viability $(>85 \%)$ of the isolated cells after CD22 depletion was determined.

INDUCTION AND ASSAY OF INTERFERON $\gamma$ Peripheral blood mononuclear cells $\left(1 \times 10^{6} / \mathrm{ml}\right)$ and lamina propria lymphocytes $\left(4 \times 10^{5} / \mathrm{ml}\right)$ were cultured with inactivated H pylori $(3 \mu \mathrm{g} / \mathrm{ml}, 300 \mu \mathrm{g} / \mathrm{ml})$, purified protein derivative $(100 \mathrm{U} / \mathrm{ml})$, phythaemagglutinin (10 $\mu \mathrm{g} / \mathrm{ml}, 5 \mu \mathrm{g} / \mathrm{ml})$, OKT3 (1:50), and RPMI 1640 only in RPMI 1640 for either five days or three days at $37^{\circ} \mathrm{C}$ in $5 \%$ carbon dioxide. The culture supernatants were collected and stored at $-70^{\circ} \mathrm{C}$.

Interferon $\gamma$ was measured by enzyme linked immunosorbent assay (ELISA) using anti-interferon $\gamma$ antibodies kindly donated by Dr Kingston Mills, National Institute for Biological Standards, UK. Purified mouse anti-interferon monoclonal $\mathrm{Ab}$ was coated (50 $\mu \mathrm{l} /$ well) onto 96 well round bottomed ELISA plates and incubated for two hours at $37^{\circ} \mathrm{C}$. The wells were then blocked overnight

TABLE III Proliferation of lamina propria lymphocytes in gastric mucosa in $\mathrm{H}$ pylori positive $(n=14)$ and negative $(n=14)$ patients

\begin{tabular}{lccl}
\hline & \multicolumn{3}{l}{${ }^{3}$ H-thymidine } \\
\cline { 2 - 4 } & H pylori $(+)$ & H pylori $(-)$ & p Value \\
\hline Phythaemagglutinin $(5 \mu \mathrm{g} / \mathrm{ml})$ & $7171(1613)$ & $7755(156)$ & $0 \cdot 32$ \\
OKT3 $(1: 50)$ & $6104(493)$ & $6213(821)$ & $0 \cdot 25$ \\
H pylori $(300 \mu \mathrm{g} / \mathrm{ml})$ & $1400(448)^{\star}$ & $3013(418)^{\star}$ & $0 \cdot 015$ \\
Spontaneous RPMI & $562(192)$ & $650(281)$ & $0 \cdot 22$ \\
Irradiated feeder cells alone & $435(110)$ & $502(150)$ & $0 \cdot 43$
\end{tabular}

Results are expressed as ${ }^{3} \mathrm{H}$-thymidine incorporation (cpm) in lamina propria lymphocytes $\left(4 \times 10^{5} / \mathrm{ml}\right)$ cultured for 72 hours with autologous irradiated $(250 \mathrm{~Gy})$ peripheral blood mononuclear cells $\left(2 \times 10^{6} / \mathrm{ml}\right)$ containing interleukin $2(2 \mathrm{U} / \mathrm{ml})$. ${ }^{\star}$ Lamina propria lymphocyte response to $H$ pylori in culture was significantly lower $(\mathrm{p}<0.02)$ in $H$ pylori positive subjects compared with $H$ pylori negative subjects. Data shown as mean (SEM). $\left(4^{\circ} \mathrm{C}\right)$ with $150 \mu \mathrm{l}$ phosphate buffered saline containing bovine serum albumin $(0.5 \%$, wt/vol).

The plates were washed four times with phosphate buffered saline-TWEEN 20 (200 $\mu \mathrm{l} /$ well). Supernatants were added ( $50 \mu \mathrm{l} /$ well) in triplicate. Triplicate serial dilutions of interferon $\gamma(100 \mathrm{IU}$ to $1.5 \mathrm{IU} / \mathrm{ml})$ were added to standard wells. The plates were incubated for one hour at $37^{\circ} \mathrm{C}$ and then washed four times with phosphate buffered saline-TWEEN 20.

Rabbit polyclonal anti-interferon $\gamma$ was added ( $50 \mu \mathrm{l} /$ well) in bovine serum albuminphosphate buffered saline and incubated for one hour at $37^{\circ} \mathrm{C}$. After washing the plates biotinylated antirabbit IgG ( $50 \mu \mathrm{l} /$ well) was added in bovine serum albumin-phosphate buffered saline and incubated for one hour at $37^{\circ} \mathrm{C}$. Strepavadin biotinylated horseradish peroxidase conjugate $(50 \mu \mathrm{l} /$ well) in bovine serum albumin-phosphate buffered saline was added and incubated for 30 minutes at $37^{\circ} \mathrm{C}$, washed four times with bovine serum albuminphosphate buffered saline followed by two washes with $0.1 \mathrm{M}$ citrate phosphate buffer (pH 5.0).

The substrate, o-phenylenediamine (1 $\mathrm{mg} / \mathrm{ml}$ in citrate phosphate buffer) was then added ( $50 \mu \mathrm{l} /$ well) and the reaction was developed in the dark at room temperature. The reaction was stopped after 10 to 15 minutes by addition of $1 \mathrm{M} \mathrm{H}_{2} \mathrm{SO}_{4}(50 \mu \mathrm{l} /$ well $)$. The plates were read using an ELISA reader at 450 nm. A standard curve was constructed and the amount of interferon $\gamma$ present in the supernatant was determined with reference to this standard curve. The assay sensitivity was 2 $\mathrm{IU} / \mathrm{ml}^{24}$

\section{LAMINA PROPRIA LYMPHOCYTE PHENOTYPIC \\ ANALYSIS}

Lamina propria lymphocytes were isolated as described above. The number and viability of the isolated cells were determined using acridine orange/ethidium bromide. One $\times 10^{5}$ cells were washed with phosphate buffered saline containing bovine serum albumin (1\%, $\mathrm{wt} / \mathrm{vol})$ and sodium azide $(0.02 \%$, wt/vol). Monoclonal antibodies including Leu 4 (CD3), Leu 3a (CD4), Leu 2a (CD8), Leu M3 (CD14), Leu 14 (CD22), and Leu 19 (CD56), control phycoerythrin and fluorescein isothiocyanate were added $(5 \mu \mathrm{l})$ to the lamina propria lymphocytes, respectively. Lymphocyte subsets were analysed by a combination of direct and indirect immunofluorescence. Data were acquired on a Beckton Dickinson FACSCAN and analysed using Lysis 3 software. Lamina propria lymphocyte phenotypic analysis was expressed as a percentage of the positive cells. All the monoclonal antibodies were obtained from Becton Dickinson Immunocytometry Systems, San Jose, CA, USA.

\section{STATISTICAL ANALYSIS}

Data are expressed as mean (SEM). Differences between the results obtained with $H$ pylori 


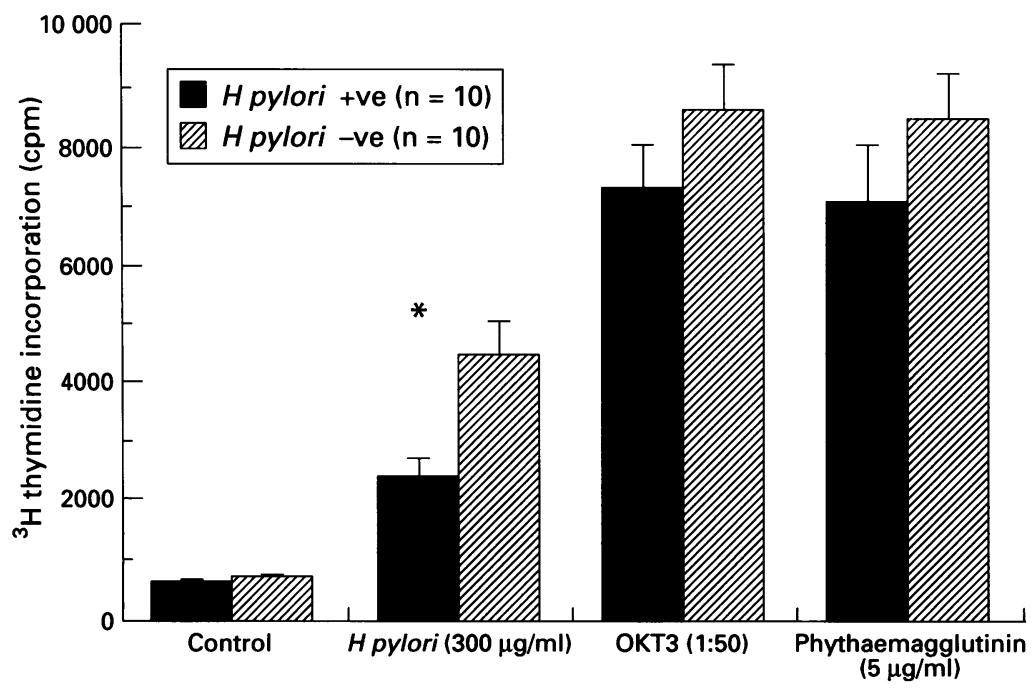

Figure 2: Response of $B$ lymphocyte depleted lamina propria $T$ lymphocytes to $\mathrm{H}$ pylori antigens. Lamina propria lymphocytes were depleted of $B$ lymphocytes by magnetic bead separation. Proliferation was assessed in the presence of irradiated peripheral blood mononuclear cells as accessory cells and interleukin 2. * Lamina propria T lymphocyte responses to $\mathrm{H}$ pylori $(300 \mu \mathrm{g} / \mathrm{ml}$ ) in culture were significantly lower in $\mathrm{H}$ pylori positive patients compared with $\mathrm{H}$ pylori negative patients $(p<0.02)$.

positive and negative groups were analysed using the two tailed Mann-Whitney U test.

\section{Results}

PROLIFERATIVE RESPONSES OF PERIPHERAL BLOOD MONONUCLEAR CELLS IN RESPONSE TO H PYLORI ANTIGEN

Lymphocyte proliferative responses were performed using $H$ pylori antigen $(3 \mu \mathrm{g} / \mathrm{ml})$, a dose found to give maximal peripheral blood mononuclear cells proliferation results in preliminary experiments. Lymphocyte proliferative responses were detected in both $H$ pylori positive and negative subjects. Proliferative responses were significantly lower in the $H$ pylori positive subjects $(\mathrm{p}<0 \cdot 02)$. No significant differences were seen between the $H$ pylori
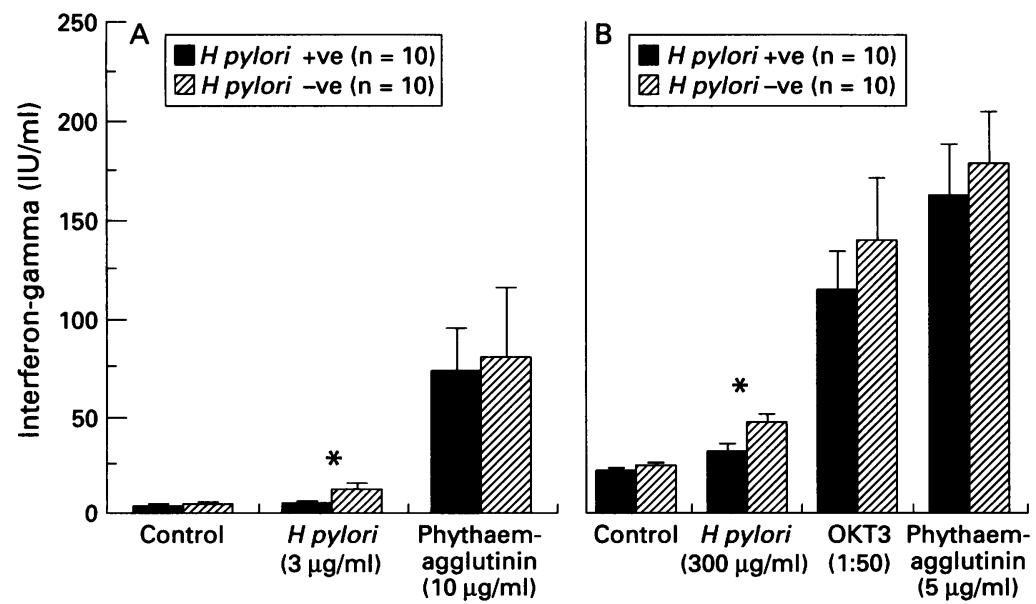

Figure 3: $(A)$ Interferon $\gamma$ production by peripheral blood mononuclear cells in culture in the presence of $\mathrm{H}$ pylori, phythaemagglutinin, and RPMI (control). Interferon $\gamma$ was measured by ELISA. * Interferon $\gamma$ production was significantly lower in $\mathrm{H}$ pylori positive patients $(p<0 \cdot 02)$ after stimulation with $\mathrm{H}$ pylori compared with negative controls. $(B)$ Interferon $\gamma$ values in the supernatant of cultured lamina propria lymphocytes. Interferon $\gamma$ was measured by ELISA. * Interferon $\gamma$ production by lamina propria lymphocytes in response to $\mathrm{H}$ pylori was significantly lower in $\mathrm{H}$ pylori infected patients $(p<0.05)$ compared with $\mathrm{H}$ pylori negative subjects. positive and negative groups in the presence of purified protein derivative, phythaemagglutinin, and $E$ coli (Table II). While proliferative response using purified protein derivative seems to be lower in the $H$ pylori positive group, this did not show statistical significance.

PROLIFERATIVE RESPONSES OF GASTRIC MUCOSA LAMINA PROPRIA LYMPHOCYTES IN RESPONSE TO $H$ PYLORI ANTIGEN

A high dose of $H$ pylori $(300 \mu \mathrm{g} / \mathrm{ml})$ resulted in optimal stimulation of lamina propria lymphocytes and this amount was used in subsequent experiments (Fig 1). This may reflect a lower efficiency of antigen processing by the irradiated antigen presenting cells used in these assays. In addition low amounts of interleukin 2 were required to induce proliferation in this system. Exogenous interleukin 2 was added at the lowest concentration that permitted measurement of proliferation. No proliferation was seen in the absence of irradiated peripheral blood feeder cells or exogenous interleukin 2 . Also no proliferation was seen in the irradiated peripheral blood feeder cells alone in the presence of interleukin 2 and $H$ pylori (Table III). Proliferation of gastric lamina propria lymphocytes was found to be maximal at three days in preliminary studies. The proliferative responses to $H$ pylori $(300 \mu \mathrm{g} / \mathrm{ml})$ were significantly lower in the $H$ pylori positive patients compared with negative patients $(p<0.02)$. There was no significant difference, however, between the two groups in their responses to phythaemagglutinin and OKT3 (Table III).

\section{B CELL ELIMINATION}

After B cell elimination from lamina propria lymphocytes, similar proliferative results were obtained. T lymphocyte responses to $H$ pylori $(300 \mu \mathrm{g} / \mathrm{ml})$ were statistically lower mean (SEM) (2356 (342) v 4425 (626) cpm, $\mathrm{p}<0.02)$ in $H$ pylori positive patients compared with the $H$ pylori negative patients. There was no significant difference, however, between the two groups in their responses to phythaemagglutinin (7021 (1023) v $8456(844), \mathrm{p}=0.325)$ and OKT3 $(7285$ (783) $v \quad 8651 \quad(744)$, $\mathrm{p}=0.251$ ) (Fig 2).

INTERFERON $\gamma$ PRODUCTION BY PERIPHERAL BLOOD MONONUCLEAR CELLS AND LAMINA PROPRIA LYMPHOCYTES IN CULTURE

Interferon $\gamma$ secretion by peripheral blood mononuclear cells in response to $H$ pylori antigen was significantly lower in $H$ pylori positive patients compared with $H$ pylori negative controls $(p<0.02)$. Neither spontaneous production of the interferon $\gamma$ or interferon $\gamma$ production in response to phythaemagglutinin $(10 \mu \mathrm{g} / \mathrm{ml})$ stimulation were significantly different in the two groups (Fig 3A). Interferon $\gamma$ secretion by lamina propria lymphocytes in response to $H$ pylori antigen was significantly lower in patients with $H$ pylori infection $(p<0.05)$. Neither spontaneous production of interferon $\gamma$ or interferon $\gamma$ production in 
TABLE IV Characterisation of lamina propria lymphocyte population

\begin{tabular}{lllllll}
\hline \multicolumn{7}{c}{ Percentage of positive cells } \\
\cline { 2 - 7 } & $C D 3$ & $C D 4$ & $C D 8$ & \multicolumn{1}{l}{ CD22 } & CD14 & CD56 \\
\hline HP+ve (n=8) & $50(4 \cdot 9)$ & $19 \cdot 2(1 \cdot 6)$ & $28(3 \cdot 1)^{\star}$ & $21(5 \cdot 2)^{\star}$ & $7 \cdot 7(1 \cdot 2)$ & $<2$ \\
HP-ve (n=8) & $55(5 \cdot 1)$ & $21 \cdot 3(3 \cdot 6)$ & $21(2 \cdot 1)^{\star}$ & $8 \cdot 4(1 \cdot 5)^{\star}$ & $6 \cdot 4(1 \cdot 4)$ & $<2$ \\
\hline
\end{tabular}

Results are expressed as a percentage of positive cells in lamina propria lymphocyte suspensions. All cells were quantitated by flow cytometry. ${ }^{\star}$ Note that there was a significant $(p<0.05)$ increase in $\mathrm{CD}^{+}$and $\mathrm{CD} 22^{+}$cells in lamina propria lymphocyte populations from $\mathrm{H}$ pylor positive subjects, but no significant difference in the number of $\mathrm{CD}^{+}, \mathrm{CD}^{+}, \mathrm{CD} 14^{+}$, and positive subjects, but no significant difference in the number of $\mathrm{CD} 3^{+}, \mathrm{CD} 4^{+}, \mathrm{CD} 14^{+}$, and
$\mathrm{CD} 56^{+}$cells from either $H$ pylori positive or negative groups. Data shown as mean (SEM).

response to phythaemagglutinin $(5 \mu \mathrm{g} / \mathrm{ml})$ and OKT3 (1:50) stimulation were significantly different in the two groups (Fig 3B).

CHARACTERISATION OF LAMINA PROPRIA

LYMPHOCYTE POPULATIONS

The percentage of CD3, CD4 (helper), CD8 (suppressor), CD22, CD14, and CD56 positive cells in lamina propria lymphocyte populations from $H$ pylori positive and negative patients was assessed by flow cytometry. There was a significant $(p<0.05)$ increase in $\mathrm{CD}^{+}$ and $\mathrm{CD}_{22}{ }^{+}$cells present in lamina propria lymphocytes subpopulations in $H$ pylori positive subjects, but no significant difference in the number of $\mathrm{CD}^{+}, \mathrm{CD}^{+}, \mathrm{CD}^{+} 4^{+}$, and $\mathrm{CD} 6^{+}$cells in $H$ pylori positive and negative groups (Table IV).

\section{Discussion}

In this study we have shown that an inactivated $H$ pylori preparation is capable of stimulating $T$ cell activation as reflected in the secretion of the $T$ cell cytokine interferon $\gamma$, as well as $T$ cell proliferation. This activation is seen not only in subjects with previous contact with $H$ pylori and established serological immunity but also in subjects who are negative for $H$ pylori colonisation. Furthermore, our data suggest a significantly attenuated response to $H$ pylori in $H$ pylori positive patients. It is conceivable that the observed lymphocyte response reported in $H$ pylori negative patients resulted from cross reactivity with certain ubiquitous bacterial antigens. Lymphocyte proliferative responses to $E$ coli, purified protein derivative or phythaemagglutinin were not different, however, when compared between the two groups.

These results from peripheral blood cultures are in agreement with those previously described. ${ }^{16} 17$ In addition to the results obtained in peripheral blood lymphocyte populations, we have now been successful in examining the proliferative responses of gastric mucosal lymphocytes isolated from endoscopic biopsy specimens. This has permitted direct analysis of antigen specific responses at the site of mucosal inflammation. Our studies have shown an increase in local $\mathrm{T}$ cells adjacent to gastric epithelial cells in response to $H$ pylori infection. ${ }^{25}$ In the development of this assay we have found that irradiated antigen presenting cells and exogenous interleukin 2 were necessary for the stimulation of proliferation. No proliferation was seen in the absence of exogenous interleukin 2 or in the presence of interleukin $2 \mathrm{U} / \mathrm{ml}$ alone (data not shown). No proliferation was seen in the irradiated peripheral blood feeder cells alone in the presence of interleukin 2 and $H$ pylori. Gastric mucosal lymphocytes were stimulated by inactivated $H$ pylori preparation in both $H$ pylori positive and $H$ pylori negative patients. Lymphocyte proliferation in $H$ pylori positive patients was, however, significantly less intense when compared with $H$ pylori negative patients. We excluded the possibility that this was a non-specific B cell response to lipopolysaccharide as we have performed these studies in lymphocyte preparations depleted of B cells by magnetic bead isolation. These results show that lamina propria $\mathrm{T}$ lymphocytes exhibit reduced proliferation in response to $H$ pylori in $H$ pylori positive patients. In addition, interferon $\gamma$ production was also reduced in $H$ pylori positive subjects. Interferon $\gamma$ production was significantly higher in lamina propria lymphocytes than in peripheral blood mononuclear cells. This may reflect a differing clonal distribution of lymphocytes producing this cytokine at these sites. Data in intestinal $T$ cell clones suggest that the majority of such $T$ cells produce interferon $\gamma$. Similarly, intestinal lamina propria lymphocytes seem to be capable of expressing interleukin 2 receptor without proliferating, a finding that suggests that little interleukin 2 is available for stimulation. 26

There are a number of potential mechanisms for this attenuated response to $H$ pylori. Firstly, $H$ pylori might produce an inhibitory factor or toxin in vivo, which blocks lymphocyte proliferation. Lymphocyte proliferation in response to the $T$ cell mitogen phythaemagglutinin and anti-CD3 is unaltered, however, by $H$ pylori infection suggesting that a nonspecific toxin is unlikely. A second mechanism could be antigen specific suppression mediated by $\mathrm{CD}^{+}$suppressor cells. In this regard it is notable that we have shown an increase in the proportion of $\mathrm{CD8}^{+}$cells in the lamina propria of $H$ pylori positive patients. It is as yet unclear whether these cells have cytotoxic potential or whether they are functioning as suppressor cells. Further studies will be directed to finding out if antigen specific $\mathrm{CD}^{+}$suppressor cells within the lamina propria may be implicated in attenuated responses to $H$ pylori. Such cells have been shown in the cutaneous lesion of lepromatous leprosy ${ }^{27}$ and are thought to play a part in the nature of the tissue response to $M$ leprae.

Many studies have shown the structure and antigenicity of $H$ pylori whole cell, outer membrane, acid extractable surface protein, and proteinase $\mathrm{K}$ treated whole cell lysate preparations from $H$ pylori strains. Antibody reactivity is quite diverse and recognises a wide range of proteins. ${ }^{28}$ It is possible that $H$ pylori positive patients recognise different epitopes than $H$ pylori negative patients. It has been reported that the presence of antibodies reacting with a $120 \mathrm{kDa}$ protein is associated with duodenal ulcer and gastric cancer and it seems that this antigen is associated with strains of increased cytotoxicity. ${ }^{29} 30$ It is 
possible that exposure to a potent immunogen from a low virulence strain may confer $T$ cell reactivity and protection from infection.

In assessing these data, it is important to consider the question of previous contact with $H$ pylori. $H$ pylori is an extremely prevalent organism with a high rate of recurrence in the year after eradication. ${ }^{31}$ Furthermore, infection may be intrafamilial or sporadic within families suggesting a wide environmental exposure. ${ }^{32}$ As yet there is little evidence for elimination of the bacteria in non-susceptible patients. The finding of lower responses to $H$ pylori, which we and others have described, however, suggest the possibility that poor $T$ cell responses may be associated with an inability to clear the organism.

$\mathrm{DK}$ is a Wellcome Senior Fellow in clinical science.

1 Warren JR, Marshall BJ. Unidentified curved bacilli on gastric epithelium in active chronic gastritis. Lancet 1983; i: tric epitheli.

2 Marshall BJ, Warren IR. Unidentified curved bacilli in the stomach of patients with gastritis and peptic ulceration. Lancet 1984; i: 1311-4.

3 Crabtree JE, Shallcross TM, Heatley RV, Wyatt JI. Mucosal tumour necrosis factor $\alpha$ and interleukin- 6 in patients with Helicobacter pylori associated gastritis. Gut 1991; 32: 1473-7.

4 Marshall BJ, Armstrong JA, McGechie DB, Glancy RJ. Attempt to fulfil Koch's postulates for pyloric Attempt to fulfil Koch's postulates for

5 Wyatt JI, Rathbone BJ, Heatley RV. Local immune response to gastric Campylobacter in non-ulcer dyspepresponse to gastric Campylobacter
sia. $f$ Clin Pathol 1986; 39: 863-70.

6 Blaser MJ. Gastric Campylobacter-like organisms, gastritis and peptic ulcer disease. Gastroenterology 1987; 93: 371-83

7 Dooley CP, Fitzgibbons PL, Cohen H, Appleman MD, Perez-Perez GI, Blaser MJ. Prevalence of Helicobacter pylori infection and histologic gastritis in symptomatic persons. N Engl f Med 1989; 321: 1562-6.

8 Graham DY. Campylobacter pylori and peptic ulcer disease. Gastroenterology 1989; 96: 615-25.

9 Wyatt JI. Campylobacter pylori, duodenitis and duodenal ulceration. In: Rathbone BJ, Heatley RV, eds. Campylobacter pylori and gastroduodenal disease. Oxford: Campylobacter pylori and gastroduoden

10 Rauws EAJ, Tytgat GNJ. Cure of duodenal ulcer associated with eradication of Helicobacter pylori. Lancet 1990; 335: with eradic

11 Blaser MJ. Helicobacter pylori and the pathogenesis of gastroduodenal inflammation. $\mathcal{F}$ Infect Dis 1990; 161: 626-33.

12 Chen XG, Correa P, Offerhaus J. Ultrastructure of the gastric mucosa harbouring Campylobacter-like organisms. Am f Clin Pathol 1989; 86: 575-82.

13 Rathbone BJ, Wyatt II, Worsley BW, Shires SE, Trejdosiewicz LK, Heatley RV, et al. Systemic and local antibody responses to gastric Campylobacter pyloridis in non-ulcer dyspepsia. Gut 1986; 27: 642-7.

14 Rauws EAJ, Tytgat GNJ. Diagnosis of Campylobacter pylori infection. In: Campylobacter pylori. Amsterdam: WC pylori infection. In: Cam

15 Blaser MJ. Hypotheses on the pathogenesis and natural history of Helicobacter pylori-induced inflammation. Gastroenterology 1992; 102: 720-7.

16 Karttunen R. Blood lymphocyte proliferation, cytokine secretion and appearance of T-cells with activation surface markers in cultures with Helicobacter pylori. Comparison of the responses of subjects with and without antibodies to $\mathrm{H}$ pylori. Clin Exp Immunol 1991; 83: 396-400.

17 Karttunen R, Andersson G, Poikonen K, Kosunen TU, Karttunen $T$, Juutinen $K$. Helicobacter pylori induces lymphocyte activation in peripheral blood cultures. Clin Exp Immunol 1990; 82: 485-8.

18 Madrigal L, Lynch S, Feighery C, Weir D, Kelleher D, O'Farrelly C. Flow cytometric analysis of surface major histocompatibility complex class II expression on human epithelial cells prepared from small intestinal biopsies. fopithelial cells prepared from small inte

19 Brennan DP, Keeling PWN. Campylobacter pylori released membrane-associated and soluble antigens during infection. In: Megraud F, Lamouliatte H, ed. Gastroduodenal pathology and Campylobacter pylori. Amsterdam: Elsevier, 1989: 207-11.

20 Bradford MM. A rapid and sensitive method for the quantitation of microgram quantities of protein utilizing the principle of protein-dye binding. Anal Biochem 1976; 72. 248-54.

21 Bartnik W, ReMine SG, Chiba M, Thayer WR, Shorter RG. Isolation and characterization of colonic intraepithelial and lamina propria lymphocytes. Gastroenterology 1980; 78: $976-85$.

22 Gaudernack G, Leivestad $T$, Ugelstad $J$, Thorsby $E$. Isolation of pure functionally active $\mathrm{CD}^{+} \mathrm{T}$ cells. Isolation of pure functionally active CD8 T cells. Positive selection with monoclonal antibodies directly
conjugated to monosized magnetic microspheres. conjugated to monosized magne

3 Kemshead JT, Health L, Gibson FM, Katz F, Richmond F, Treleaven J, et al. Magnetic microspheres and monoclonal antibodies for the depletion of neuroblastoma cells from bone marrow. Experiences, improvements and observations. Br f Cancer 1986; 54: 771-8.

24 Meager A. Antibodies against interferons: characterization of interferons and immunoassays. In: Clemens $\mathbf{M}$, Morris A, Gearing A, eds. Lymphokines and interferons. Oxford: ARL press, 1987: 105-27.

25 Trejdosiewicz LK, Calabrese A, Smart CJ. $\gamma \delta$ T-cell receptor-positive cells of the human gastrointestinal mucosa: occurrence and V region gene expression in Helicobacter occurrence and V region gene expression in Helicobacter pylori-associated gastritis, coeliac disease and inflamma-
tory bowel disease. Clin Exp Immunol 1991; 84: 440-4.

26 Lundin KEA, Scott H, Hansen T, Paulsen G, Halstensen TS, Fansa O, et al. Gliadin-specific HLA DQ $\left(\alpha 1{ }^{\star} 0501\right.$, $\beta \star 0201)$ restricted T cells isolated from the small intestinal mucosa of coeliac disease patients. F Exp Med 1993; 178: $187-96$.

27 Modlin RL, Mehra V, Wong L, Fujimiya Y, Chang W, Horwitz D, et al. Suppressor T lymphocytes from lepromatous leprosy skin lesions. $\mathcal{f}$ Immunol 1986; 137: 2831-4.

28 Perez-Perez GI, Blaser MJ. Conservation and diversity of Campylobacter pyloridis major antigens. Infect Immun 1987; 55: 1256-63.

29 Crabtree JE, Taylor JD, Wyatt JI, Heatley RV, Shallcross TM, Tompkins DS, et al. Mucosal IgA recognition of Helicobacter pylori $120 \mathrm{kDa}$ protein, peptic ulceration, and gastric pathology. Lancet 1991; 338: 332-5.

30 Crabtree JE, Wyatt JI, Sobala GM, Miller G, Tompkins DS, Primrose JN, et al. Systemic and mucosal humoral responses to Helicobacter pylori in gastric cancer. Gut 1993; 34: 1339-43.

31 Coghlan JG, Gilligan D, Humphries H, McKenna D, Dooley C, Sweeney E, et al. Campylobacter pylori and recurrence of duodenal ulcer - a 12-month follow-up study. Lancet 1987; ii: 1109-11.

32 Collins JSA Bamford KB, Bickley J, Johnston BT, Sloan $\mathrm{JM}$, Boston VE, et al. Comparison of $\mathrm{H}$ pylori strains from infected parents and off-spring using DNA typing. Gut 1992; 33 (suppl 1): S3. 